\title{
УДОСКОНАЛЕННЯ ПРОЦЕСУ ДОСТАВКИ ВОДИ ПІД ЧАС ГАСІННЯ ЛІСОВИХ ПОЖЕЖ
}

\begin{abstract}
Проаналізовано сучасні способи доставки води до місць гасіння лісових пожеж, а також наведено їх основні переваги та недоліки. Встановлено, що найперспективнішим для України способом доставки води до місця гасіння лісових пожеж 3 урахуванням закордонного досвіду є залучення до транспортного процесу багатофункціональних мобільних аварійно-рятувальних комплексів зі знімними кузовами-контейнерами. З'ясовано, що організація доставки води способом ії підвозу в разі залучення до цього процесу вказаного виду транспортних засобів потребує попереднього обгрунтування їх чисельності. Запропоновано удосконалений розрахунковий метод визначення чисельності багатофункціональних мобільних аварійно-рятувальних комплексів зі знімними кузовами-контейнерами під час організації процесу доставки води до місця гасіння лісових пожеж за рахунок врахування коефіцієнта об'ємних втрат води з цистерни, показника середнього часу, який затрачається водієм автомобіля-носія на виконання маневрів на пункті заправки, показника середнього часу, що затрачається водієм автомобіля-носія на виконання маневрів на пункті витрати і показника середнього часу, котрий затрачається на приведення пожежного насосу кузова-контейнера у робочий стан та приєднання його напірного патрубка до рукавної лінії на пункті вит-
\end{abstract} рати.

Ключові слова: багатофункціональний мобільний аварійно-рятувальний комплекс; пожежно-рятувальний підрозділ; транспортний процес; керівник гасіння пожежі.

Вступ. Однією з вагомих проблем, яка супроводжує людство впродовж тисячоліть його існування, $є$ пожежі. Розміри збитків від пожеж чимало дослідників порівнює зі збитками, які було завдано війнами.

Проаналізувавши розподіл кількості пожеж за об'єктами їх виникнення в Україні (Analysis, 2017), можна прийти до висновку, що найбільшу питому вагу становлять пожежі на відкритих територіях, зокрема в лісових масивах. У 2017 р. кількість пожеж у лісових масивах, порівняно з минулими роками, збільшилась у 3 рази, а на торфовищах - у 2,8 раза. Процес ліквідації лісових пожеж пожежно-рятувальними підрозділами (ПРП) потребує значних об'ємів води, а тому до їх гасіння залучається достатньо багато сил та засобів. Успіх процесу пожежогасіння значно залежить від ефективної організації доставки води до місця гасіння пожеж в лісі, що ускладнюється станом дорожнього покриття та територіальною віддаленістю вододжерел, а тому ця проблема у процесі виконання оперативних робіт ПРП є актуальною.

Аналіз останніх досліджень і публікацій. У роботі (Murgatroyd, 2002) проаналізовано порядок організації гасіння пожеж на відкритих територіях та встановлено, що до цього процесу активно залучаються гелікоптери, які оснащуються водозливними пристроями. Окрім цього, з'ясовано, що гелікоптери через значну купівельну вартість і вартість експлуатації можуть орендуватися місцевою владою, яка несе відповідальність за гасіння пожеж, у сторонніх організацій і надалі використовуватися для цілей пожежогасіння, зокрема розвідки пожежі.

У роботі (Chi, Youmin \& Zhixiang, 2015) встановлено, що впродовж останніх десятиліть за кордоном у процесі гасіння пожеж на відкритих територіях часто використовують безпілотні літальні апарати. Основним завданням безпілотних літальних апаратів $€$ моніторинг оперативної обстановки, яка пов'язана 3 виникненням та поширенням пожеж, окрім цього, дослідники стверджують, що цей вид технічних засобів може бути використано для гасіння пожеж на ранніх стадіях їх розвитку. Головними проблемами, які обмежують ширше використання безпілотних літальних апаратів, $є$ їх висока купівельна вартість і невеликий об'єм вогнегасних речовин, який вони можуть доставляти до осередку пожежі.

У Німеччині та Австрії згідно з дослідженнями (Kaulfuß \& Hofmann, 2011), до процесу доставки води під час гасіння лісових пожеж залучаються переважно спеціалізовані повнопривідні автомобілі зі значним кліренсом (наприклад, TLF 20/50 типу "Бранденбург"), які мають пожежно-технічне оснащення й обладнані пожежним насосом. Доставка води за допомогою гелікоптерів, які $є$ основним видом авіаційної техніки, яка залучається для гасіння лісових пожеж, відбувається переважно під час виконання оперативних робіт у гірських районах. Враховуючи те, що гелікоптери з водозливними пристроями у зазначених країнах перебувають на озброєнні лише у поліції, армії та приватних організа-

\section{Інформація про авторів:}

Коваленко Роман Іванович, канд. техн. наук, ст. викладач, кафедра інженерної та аварійно-рятувальної техніки. Email: pandora.kr@ukr.net; https://orcid.org/0000-0003-2083-7601

Цитування за ДСтУ: Коваленко Р. І. Удосконалення процесу доставки води під час гасіння лісових пожеж. Науковий вісник НлТУ України. 2019, т. 29, № 2. С. 127-130.

Citation APA: Kovalenko, R. I. (2019). Improving the process of water delivery in extinguishing a forest fire. Scientific Bulletin of UNFU, 29(2), 127-130. https://doi.org/10.15421/40290226 
цій, то вони залучаються до гасіння пожеж тільки як допоміжні технічні засоби.

У роботі (Dermek, 2017) дослідники проаналізували такі способи доставки води: перекачування води за допомогою потужних насосів від джерел водопостачання по рукавних лініях до місця пожежогасіння; підвезення води із залученням пожежних автоцистерн з великими місткостями від пункту заправки до місця пожежогасіння; комбінований спосіб, який одночасно поєднує два попередньо названих способи. Недоліком першого способу є те, що в разі використання насосів високого тиску для перекачування води на великі відстані рукави, які знаходяться ближче до них, під дією надмірного тиску часто рвуться, а це $\epsilon$ причиною виникнення перебоїв у подачі вогнегасної речовини до осередку пожежі. Перевагами цього способу є те, що під час затяжних пожеж, за умови наявності необхідної кількості сил та засобів і вододжерел зі значними запасами води, можливо забезпечити стабільну подачу вогнегасних речовин до осередку пожежі. До основних недоліків другого способу доставки води дослідники віднесли складність виконання маневрів автоцистерною в умовах лісової місцевості через значні їі габарити, утрудненість пересуван- ня автоцистерн важкого типу по грунтовому або піщаному дорожньому покриттю та складність організації транспортного процесу за умови залучення великої кількості автомобілів. На думку дослідників, цей спосіб $\epsilon$ найефективнішим на початковій стадії пожежогасіння при доставці води на відстані понад 2 км, а також до переваг цього способу можна віднести те, що не треба витрачати час на прокладання достатньо довгих магістральних рукавних ліній.

Упродовж тривалого часу за кордоном на озброєнні ПРП перебувають багатофункціональні мобільні аварійно-рятувальні комплекси (БМАРК) зі знімними кузовами-контейнерами (рисунок). Названі технічні засоби мають знімні кузови-контейнери, які конструктивно виконані взаємозамінними, а це дає змогу використовувати для їх перевезень майже будь-який автомобіль-носій, який має вантажну платформу необхідних розмірів та вантажно-розвантажувальний механізм певної конструкції, що можна вважати їх істотною перевагою порівняно із "класичними" оперативними транспортними засобами, якими на сьогодні озброєні більшість ПРП (Fisher, 2005; Avsec, 2014).

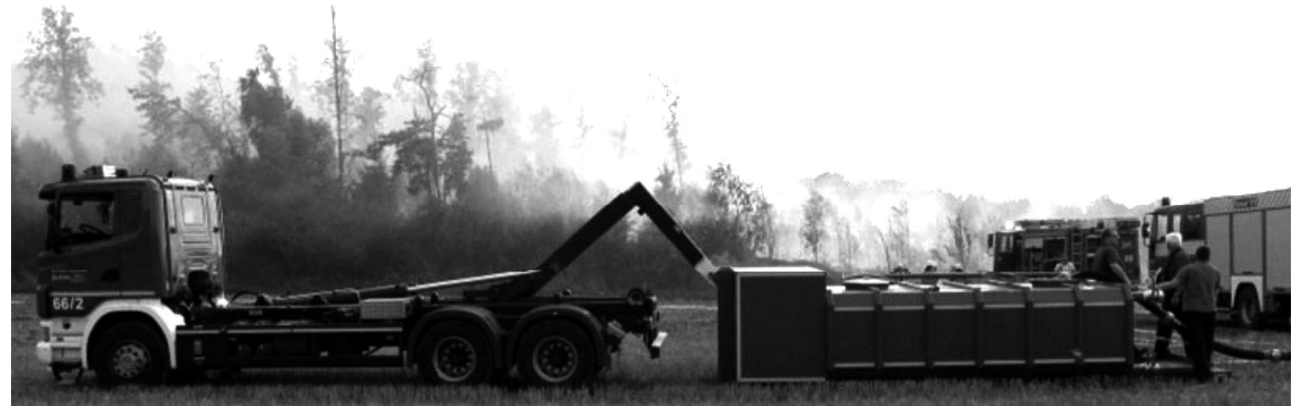

Рисунок. БМАРК зі знімним кузовом-контейнером

В Україні БМАРК зі знімними кузовами-контейнерами не перебувають на озброєнні підрозділів ПРП, але дане питання $\epsilon$ на сьогодні досить актуальним. У дослідженнях (Renkas \& Sy'chevs'ky'j, 2019) зазначено, що використання БМАРК зі знімними кузовами-контейнерами у діяльності ПРП України дало б змогу підвищити ефективність виконання ними оперативних робіт.

Отже, для доставки води під час гасіння лісових пожеж використовують різні технічні засоби і, відповідно, способи. Кожен з цих способів має свої межі ефективного використання і обирається керівником гасіння пожежі залежно від конкретних умов. Доставка вогнегасних речовин повітряним транспортом економічно $є$ вартіснішою порівняно 3 доставкою їх наземними транспортними засобами, що є основним недоліком цього способу доставки. Ефективність доставки води до місця гасіння лісових пожеж наземним транспортом залежить від правильності організації транспортного процесу, що потребує врахування багатьох чинників та використання системного підходу.

Постановка задачі та її вирішення. Метою цього дослідження є підвищення ефективності процесу доставки води до місця гасіння лісових пожеж шляхом удосконалення розрахункового методу оцінки чисельності транспортних засобів, яких потрібно залучити до перевезення. Як методи досліджень було використано системний аналіз і синтез.

3 проведеного аналізу літературних та Інтернет-джерел встановлено, що одним з найбільш перспективних і економічно ефективних способів доставки води до місць гасіння лісових пожеж $є$ організація іiі підвозу 3 залученням до транспортного процесу БМАРК зі знімними кузовами-контейнерами. Організація доставки води способом іiї підвозу навіть 3 використанням "класичних" оперативних транспортних засобів є досить складною задачею, а в разі залучення до транспортного процесу БМАРК зі знімними кузовами-контейнерами ця задача ще більше ускладнюється.

Для забезпечення безперебійної доставки води способом підвозу однією із головних задач керівника гасіння пожежі $є$ визначення потрібної чисельності транспортних засобів, яких необхідно залучити до транспортного процесу. Для вирішення цієї задачі керівник гасіння пожежі використовує розрахунковий метод, який наведено у довіднику (Ivannikov \& Klius, 1987).

Відповідно до цього методу (Ivannikov \& Klius, 1987), кількість рухомого складу автомобільного транспорту визначають за такою формулою:

$$
N_{\text {авт. }}=\frac{2 \tau_{\text {прямув. }}+\tau_{\text {запов. }}}{\tau_{\text {витр. }}}+1,
$$

де: $\tau_{\text {прямув. }}-$ середня тривалість прямування автомобіля від пункту заправки до місця пожежогасіння, хв; $\tau_{\text {запов. }}$ - тривалість заповнення цистерни автомобіля водою, хв; $\tau_{\text {витр. }}$ - тривалість витрати води з цистерни автомобіля на місці пожежогасіння, хв.

Тривалість прямування автомобіля від місця пожежі до вододжерела визначають за такою формулою: 


$$
\tau_{\text {ррямув. }}=L \cdot 60 / V_{\text {руху }},
$$

де: $L$ - відстань від місця пожежі до вододжерела, км; $V_{\text {руху }}$ - середня швидкість руху автомобіля, км/год.

Тривалість заповнення цистерни автомобіля водою визначають за такою формулою:

$$
\tau_{\text {запов. }}=V_{u} / Q_{H} \cdot 60,
$$

де: $V_{u}-$ об'єм цистерни автомобіля, л; $Q_{H}$ - середня подача води насосом, яким заправляють цистерну автомобіля, або витрата води із пожежної колонки, яка встановлена на гідрант, л/с.

Тривалість витрати води з цистерни автомобіля на місці пожежогасіння визначають за такою формулою:

$$
\tau_{\text {витр. }}=V_{u} / N_{n p} \cdot Q_{n p} \cdot 60,
$$

де: $N_{n p}$ - кількість приладів подачі води до осередку горіння; $Q_{n p}$ - витрата приладів, л/с.

За умови оснащення ПРП БМАРК зі знімними кузовами-контейнерами та в разі подальшого їх залучення до процесу гасіння пожеж на відкритих територіях проаналізовано, розрахунковий метод, який наведено у довіднику (Ivannikov \& Klius, 1987), не дає змоги ефективно визначити необхідну кількість названої техніки, яку потрібно залучити до процесу доставки води способом підвозу.

Пояснити це можна тим, що він не враховує таких показників:

- часу завантаження та розвантаження кузова-контейнера;

- часу виконання маневру (розворот, під"їз, від'їз, завантаження та розвантаження кузова-контейнера) автомобіля-носія біля кузова-контейнера під час його завантаження або розвантаження;

- коефіцієнта об'ємних втрат води;

- часу на приведення пожежного насосу кузова-контейнера у робочий стан та приєднання його напірного патрубка до рукавної лінії на пункті витрати.

Встановлені особливості можна вважати недоліками розрахункового методу (Ivannikov \& Klius, 1987), а тому для ефективнішої організації доставки води до місця гасіння лісових пожеж методом підвозу, в разі залучення до цього процесу БМАРК зі знімними кузовами-контейнерами, потрібно удосконалити цей метод шляхом урахування зазначених показників.

3 урахуванням розрахункових формул (1)-(4) та наведених вище показників, у кінцевому вигляді формула, за якою можна визначити чисельність БМАРК зі знімними кузовами-контейнерами, які необхідні для організації доставки води способом підвозу іiї до місця гасіння пожежі, матиме такий вигляд:

$$
N_{\text {БMAPK }}=\frac{\frac{2 \cdot L \cdot 60}{V_{p y x y}}+\frac{V_{u} \cdot \beta}{Q_{\text {Hac }} \cdot 60}+\tau_{1}^{M}}{\frac{V_{u} \cdot \beta}{N_{n p} \cdot Q_{n p} \cdot 60}+\tau_{2}^{M}+\tau_{n}}+1,
$$

де: $\beta$ - коефіцієнт об'ємних втрат води з цистерни; $\tau_{1}^{M}-$ середня тривалість, який затрачається водієм автомобіля-носія на виконання маневрів (розворот, під'їзд, від'їзд, завантаження та розвантаження кузова-контейнера) на пункті заправки, хв; $\tau_{2}^{M}$ - середня тривалість, який затрачається водієм автомобіля-носія на виконання маневрів (розворот, під'їзд, від'їзд, завантаження та розвантаження кузова-контейнера) на пункті витрати, хв; $\tau_{n}$ - середня тривалість на приведення пожежного насосу кузова-контейнера у робочий стан та приєднання його напірного патрубка до рукавної лінії на пункті витрати, хв.

Середні значення коефіцієнта $\beta$ та показників $\tau_{1}^{M}$, $\tau_{2}^{\mu}$ i $\tau_{n}$ можна буде визначити у процесі проведення експериментальних досліджень за умови наявності відповідних технічних засобів (БМАРК зі знімними кузовами-контейнерами).

Висновки. Отже, за результатами проведених досліджень встановлено, що для доставки води під час гасіння лісових пожеж у розвинених країнах світу використовують різні технічні засоби і, відповідно, способи. Найперспективнішим для України способом доставки води до місця гасіння лісових пожеж з урахуванням закордонного досвіду є залучення до транспортного процесу БМАРК зі знімними кузовами-контейнерами. У цій роботі запропоновано удосконалений розрахунковий метод визначення чисельності БМАРК зі знімними кузовами-контейнерами під час організації процесу доставки води до місця гасіння лісових пожеж за рахунок врахування коефіцієнта об'ємних втрат води з цистерни, показника середнього часу, який затрачається водієм автомобіля-носія на виконання маневрів на пункті заправки, показника середнього часу, що затрачається водієм автомобіля-носія на виконання маневрів на пункті витрати і показника середнього часу, котрий затрачається на приведення пожежного насосу кузоваконтейнера у робочий стан та приєднання його напірного патрубка до рукавної лінії на пункті витрати.

У подальших дослідженнях плануємо розробити програмний засіб, який дасть змогу керівнику гасіння пожежі скоротити тривалість визначення необхідної чисельності транспортних засобів для їх залучення до процесу доставки води способом їі підвозу.

\section{Перелік використаних джерел}

Analysis. (2017). Analysis of the array of fire fighting cards for the 12 months of 2017. Retrieved from: http:/undicz.dsns.gov.ua/files/Статистика/2017/AD 12 2017.pdf. [In Ukrainian].

Avsec, R. (2014). 5 reasons to consider a modular fire truck. Fire Rescue. Retrieved from: https://www.firerescue1.com/fireproducts/fire-apparatus/articles/1934433-5-reasons-to-consider-a$\underline{\text { modular-fire-truck/ }}$

Chi, Y., Youmin, Z., \& Zhixiang, L. (2015). A survey on technologies for automatic forest fire monitoring, detection, and fighting using unmanned aerial vehicles and remote sensing techniques. Canadian Journal of Forest Research, 45, 783-792. Retrieved from: https://doi.org/10.1139/cjfr-2014-0347

Dermek, M. (2017). The parameters of the optimal method of water transport to forest fires. Procedia Engineering, 192, 96-100. https://doi.org/10.1016/j.proeng.2017.06.017

Fisher, K. (2005). The vehicles of the fire department. Frenkish-Krumbakh: Edition XXL.

Ivannikov, V. P., \& Klius, P. P. (1987). Directory of fire extinguishing. Moscow: Stroiizdat. [In Russian].

Kaulfuß, S., \& Hofmann, F. (2011). Waldbrandbekämpfung. Retrieved from: https://www.waldwissen.net/ waldwirtschaft/schaden/brand/fva waldbrand wb7 1/fva waldbra nd wb7 zf wb bekaempfung ka 1104 26.pdf

Murgatroyd, I. (2002). Technical Note by Ian R Murgatroyd of Forest Research. Forest and Moorland Fire Suppression. Retrieved from: https://www.forestry.gov.uk/pdf/FCTN3.pdf/\$FILE/FCTN3.pdf

Renkas, A. G., \& Sy'chevs'ky'j, M. I. (2019). The concept of creating a multipurpose fire and rescue car of container type. Retrieved from: http://ubgd.lviv.ua:8080/handle/123456789/831. [In Ukrainian]. 


\section{IMPROVING THE PROCESS OF WATER DELIVERY IN EXTINGUISHING A FOREST FIRE}

In Ukraine, in recent years, the number of forest fires has increased by almost three times, and therefore, the issues of increasing the fire-fighting efficiency of fire departments are up-to-date. As a research method, the systems approach, system analysis and synthesis were used. Analyzed the existing methods of delivering water to the places of extinguishing forest fires, and also identified their main advantages and disadvantages. It is established that the most promising way for Ukraine to deliver water to the place of forest fire suppression, taking into account foreign experience, is the involvement of multifunctional mobile rescue complexes with removable body-containers in the transport process. It was established that the organization of delivery of water by means of its transportation with the involvement of this type of vehicles requires a preliminary justification of their number. The existing approach to the justification of the number of vehicles in the organization of the delivery of water by the way of its transportation to the place of the operational work has a number of disadvantages. The purpose of this study is to increase the efficiency of the process of delivering water to the place of extinguishing forest fires by improving the estimated method of estimating the number of vehicles that need to be involved in transportation. An improved method for calculating the number of multifunctional mobile rescue systems with removable container bodies when organizing the process of delivering water to the site of extinguishing forest fires, taking into account the coefficient of volume loss of water from the tank, the average time spent by the carrier vehicle to perform maneuvers at the refueling point, the average time spent by the driver of the road carrier on the maneuvers at the point of expenditure, and the average time spent on bringing the fireman sa body container in working condition and connection of its discharge nozzle to the hose at the point of consumption. In further studies, it is planned to develop a software tool that will allow firefighters to reduce the time needed to determine the number of vehicles for their involvement in the process of delivering water by the method of transporting it.

Keywords: multifunctional mobile rescue complex; fire and rescue unit; transport process; Head of Fire Extinguishment. 